\title{
Microstructure and $\mathrm{Pb}^{2+}$ Adsorption Properties of Blast Furnace Slag and Fly Ash based Geopolymers
}

\author{
T. J. Medina ${ }^{1}$, S. P. Arredondo ${ }^{1, *\left(\mathbb{D}, \text { R. } \text { Corral }^{1}{ }^{1}\left(\mathbb{C}, \text { A. Jacobo }^{2} \text {, R. A. Zárraga }\right.\right.}{ }^{2}$, C. A. Rosas $^{1}{ }^{(\mathbb{O}}$, \\ F. G. Cabrera ${ }^{1}$ (I) and J. M. Bernal ${ }^{3}$
}

1 Facultad de Ingeniería Mochis, Universidad Autónoma de Sinaloa, Los Mochis, Sinaloa 81223, Mexico; teresita.medina@uas.edu.mx (T.J.M.); ramon.corral@uas.edu.mx (R.C.); carlos.arc@uas.edu.mx (C.A.R.); guadalupe.cabrera@uas.edu.mx (F.G.C.)

2 Departamento de Química, División de Ciencias Naturales y Exactas, Universidad de Guanajuato, Guanajuato 36050, Mexico; aazuara@ugto.mx (A.J.); rzarraga@ugtomx.onmicrosoft.com (R.A.Z.)

3 Escuela de Ingeniería Mazatlán, Universidad Autónoma de Sinaloa, Mazatlán, Sinaloa 82146, Mexico; jmbernalc@uas.edu.mx

* Correspondence: paola.arredondo@uas.edu.mx; Tel.: +52-668-137-3320

Received: 11 August 2020; Accepted: 11 September 2020; Published: 13 September 2020

\begin{abstract}
In this study, a blast furnace slag (BFS) and fly ash (FA) based adsorbent geopolymer to be used for removing $\mathrm{Pb}^{2+}$ from aqueous solutions were synthesized using the hydrothermal method at $60{ }^{\circ} \mathrm{C}$ for $24 \mathrm{~h}$, and then cured at $25^{\circ} \mathrm{C}$ for another six days. The alkali activator applied in this work was a combination of sodium hydroxide and sodium silicate solutions at a mass ratio of 2 . The geopolymer slurry was adjusted to a Si/Al molar ratio of 3. A BFS-based geopolymer (GS) having a specific area of $23.56 \mathrm{~m}^{2} / \mathrm{g}$ and pore size and volume of $7.8 \mathrm{~nm}$ and $73 \mathrm{~cm}^{3} / \mathrm{kg}$, respectively, surpassed the raw material surface by approximately 13 -fold. An FA-based geopolymer (GA) having a specific area of $35.97 \mathrm{~m}^{2} / \mathrm{g}$ and a size and porous volume of $9 \mathrm{~nm}$ and $124 \mathrm{~nm}$, respectively, surpassed the raw material surface by approximately 23 -fold. In addition, GS and GA showed a cation exchange capacity (CEC) of 241.30 and $286.96 \mathrm{Meq} / 100 \mathrm{~g}$, respectively. X-ray diffraction (XRD) determined sample crystallinity and it was proven by scanning electron microscopy (SEM), showing that both geopolymers were constituted of unreacted particles surrounded by amorphous and semi-amorphous products. Through Fourier transform infrared spectroscopy (FTIR), a band that was assigned to the asymmetric stretching vibration of Si-O-M $\left(\mathrm{M}=\mathrm{Na}^{+}\right.$and/or $\left.\mathrm{Ca}^{2+}\right)$ non-bridging oxygen type was observed, which suggested that $\mathrm{Na}$ and $\mathrm{Ca}$ could serve as exchangeable ions in the ionic exchange process. Adsorption test data indicated that good adsorption was obtained when a neutral $\mathrm{pH}$ was used at room temperature, and the adsorption isotherm showed that GA had more adsorption sites than GS, which meant greater maximum adsorption capacity.
\end{abstract}

Keywords: adsorbent geopolymers; blast furnace slag; fly ash; ion exchange; heavy metals

\section{Introduction}

Urbanization and industrialization have led to serious problems for the environment due to the heavy metal pollution in wastewater. It is estimated that industrial activity in México will generate a wastewater volume that is close to 2.1 millions of square meters by 2030 [1]. Heavy metals are highly hazardous pollutants, because of their high toxicity, non-degradability, and tendency to accumulate in living organisms [1-4]. Several studies have identified industrial wastewater sources containing lead, which include metal smelting processes, the manufacture of lead-based paints, metallurgy, mining, and alloys $[5,6]$. Waste emissions from these industries are the main cause of lead contamination in food, as they accumulate in animal tissues and organs and, subsequently, go into the production 
of meat, milk, and eggs. Fertilizer utilization in agriculture also causes metal pollution through the accumulation in vegetables and leaves [7-9]. Lead can be found to be dissolved in sulphate and hydroxide forms; at an acid $\mathrm{pH}$, it remains a divalent cation. The main entry route of this metal into organisms are intake and inhalation. Human body in adult age can absorb an average of $10-15 \%$ of the ingested quantity [10]. Its residence time is from 20 to 40 days in the blood and from 10 to 30 years in tissues and bones, thus it mainly accumulates in bones, kidneys, and liver. An excess of lead in the human body can cause encephalopathy, psychomotor abnormalities, kidney, liver, and hematological system damage (hypertension and cardiovascular), as well as lung, stomach, brain, and kidney cancer [11-14]. Environmental levels of lead have increased more than 1000-fold in the last three centuries [15]. Because of anthropogenic activities, it is the most common heavy metal in wastewater [11,16].

Various heavy metal removal methods for wastewater have been used, including chemical precipitation, membrane filtration, adsorption, etc. [17-19]. Each method has advantages; nevertheless, industries tend to choose the cheapest option. Adsorption by ion exchange is a viable option, because of its high efficiency and simplicity. It is a process in which ions in aqueous solution are transferred (since they are attracted by electrostatic charges) to a solid matrix, which releases a different kind of ions with equal charge [20-23]. Zeolites and activated carbons are some of materials used for metal removal by adsorption due to their high surface area and porosity; however, these materials are quite expensive due to the depletion of raw material sources and the high energetic requirements of the synthesis process. For this reason, further investigation is needed to develop new and better options that solve the lead-contaminated wastewater problem [24,25]. Geopolymers have been explored as an economic, effective, and ecofriendly heavy metal adsorbent $[25,26]$. These materials are the amorphous equivalent of zeolites, because they are three-dimensional inorganic polymers of alkaline aluminosilicates, constituted of chains of $\mathrm{AlO}_{4}$ and $\mathrm{SiO}_{4}$ tetrahedra and linked together by shared oxygen atoms. Zeolites are highly crystalline, and geopolymers are mainly amorphous and semi-amorphous. The network that constitutes these materials is negatively charged, due to the $\mathrm{Al}^{3+}$ generated from being linked to four oxygens [27-31]. This charge is compensated by cations that are trapped in intracrystalline spaces; these ions are easily interchangeable, and this peculiarity gives the geopolymer the ability to attract ions. Unlike zeolites, geopolymer synthesis requires low temperature and, in general, several wastes, such as industry by-products, can be used as aluminosilicate sources in geopolymer synthesis [32-36]. Blast furnace slag (BFS) is a non-metallic residual material of steel fabrication. Blast furnaces are fed with controlled mixes of iron ore $\left(\mathrm{Fe}_{2} \mathrm{O}_{3}+\mathrm{SiO}_{2}\right)$, coke $(\mathrm{C})$, and limestone $\left(\mathrm{CaCO}_{3}\right)$, and they operate at temperatures around $2000{ }^{\circ} \mathrm{C}$. The resulting material is steel and remnant slag [37]. In total, the Mexico steel sector generates more than four million tons per year of BFS, of which $70 \%$ is reused in productive processes as substitutes and $30 \%$ is accumulated in landfills [38]. However, fly ash (FA) is produced from burning pulverized coal in electric power generating plants. It is a fine-grained, powdery particulate material that is collected from the exhaust gases by electrostatic precipitators. In México, the combustion of one ton of coal generates an average of 80 to $250 \mathrm{~kg}$ of FA, and its utilization is only 1/4th of the total production worldwide [37]. The use of these two materials is essential to mitigating landfill and environmental issues that are associated with waste disposal, which increases the recycling of by-products. The main purpose of this research is to contribute to solving these environmental pollution problems by synthetizing alkali-activated BFS- and FA-based geopolymers for use as an adsorbent of $\mathrm{Pb}^{2+}$, determining the effect of $\mathrm{pH}$ and initial concentration, as well as assessing cationic exchange capacity and studying its behavior as an adsorbent in an aqueous medium. 


\section{Materials and Methods}

\subsection{Materials}

Altos Hornos de México, S.A.B. de C.V., which is located in Monclova, Cohahuila, México, provided the BFS used in this study. The FA was obtained from the thermal power plant José López Portillo, located in Nava city, México. The chemical composition (Table 1) was determined by X-ray fluorescence (XRF) while using a Bruker S4 Pioneer (Centro de Investigaciones en Óptica A.C. (CIO), León, Gto., México).

Table 1. Chemical composition of raw materials in percentage (\%).

\begin{tabular}{ccccccccccc}
\hline Sample & $\mathbf{S i O}_{\mathbf{2}}$ & $\mathbf{A l}_{\mathbf{2}} \mathbf{O}_{\mathbf{3}}$ & $\mathbf{N a}_{\mathbf{2}} \mathbf{O}$ & $\mathrm{TiO}_{\mathbf{2}}$ & $\mathbf{F e}_{\mathbf{2}} \mathbf{O}_{\mathbf{3}}$ & $\mathbf{M n O}$ & $\mathbf{M g O}$ & $\mathbf{C a O}$ & $\mathbf{K}_{\mathbf{2}} \mathbf{O}_{2}$ & $\mathbf{P}_{\mathbf{2}} \mathbf{O}_{\mathbf{5}}$ \\
\hline BFS & 32.6 & 10.9 & 9.12 & 0.99 & 1.16 & 0.47 & 8.73 & 34.9 & 0.74 & 0.05 \\
FA & 61.9 & 19.3 & 0.79 & 1.49 & 4.29 & 0.08 & 2.0 & 8.28 & 1.0 & 0.11 \\
\hline
\end{tabular}

The raw BFS was supplied with agglomerated particles with average size of $3.7 \mathrm{~cm}$, and they were subjected to a size reduction process by grinding; this process was carried out in a rotating balls mill with nineteen steel ball of $540 \mathrm{~g}$ each for a period of $2 \mathrm{~h}$; with this grinding time, finer and non-agglomerated particles are obtained that facilitate the synthesis of geopolymers [39]. The BFS resulted in milling, and the FA were sectioned with sieving (45 $\mu \mathrm{m}$ ASTM E11-95 [40]) to obtain a surface area of $1.79 \mathrm{~m}^{2} / \mathrm{g}$ and $1.37 \mathrm{~m}^{2} / \mathrm{g}$ for the BFS and $\mathrm{FA}$, respectively.

For the alkali activator solution (AAS), a mix of sodium hydroxide $(\mathrm{NaOH})$ pellets with $\pm 97 \%$ purity, containing sodium carbonate $\left(\mathrm{Na}_{2} \mathrm{CO}_{3}\right)$ in $1 \%$ at $10 \mathrm{M}$ and sodium silicate solution $\left(\mathrm{Na}_{2} \mathrm{O}_{3} \mathrm{Si}\right)$ with a modulus $\left(\mathrm{SiO}_{2} / \mathrm{Na}_{2} \mathrm{O}\right.$ ratio) of 2.8 was used. The mix was obtained according to a mass ratio $\left(\mathrm{Na}_{2} \mathrm{OSiO}_{3} / \mathrm{NaOH}\right)$ of 2 .

Aluminum hydroxide $\left(\mathrm{Al}(\mathrm{OH})_{3}\right)$ containing aluminum oxide $\left(\mathrm{Al}_{2} \mathrm{O}_{3}\right)$ between $50 \%$ and $57.5 \%$ was used as the source of aluminum (AS).

Distilled water with a $\mathrm{pH}$ between 6 and 7.5 and total dissolved solids between 2 and $5 \mathrm{mg} / \mathrm{L}$ was used as the solvent for $\mathrm{NaOH}$.

The aqueous $\mathrm{Pb}^{2+}$ solution was prepared by dissolving $\mathrm{Pb}\left(\mathrm{NO}_{3}\right)_{2}$ in deionized water (standard solution). The concentration was diluted before the adsorption experiment. The $\mathrm{pH}$ value of the $\mathrm{Pb}^{2+}$ solution was adjusted while using $0.1 \mathrm{M} \mathrm{HNO}_{3}$ and $0.1 \mathrm{M} \mathrm{NaOH}$.

\subsection{Geopolymer Synthesis}

BFS and FA were individually combined with AS, and then mechanically mixed with the AAS to create a geopolymer slurry that was adjusted to a mass molar ratio $\mathrm{Si} / \mathrm{Al}$ of 3 . BFS-based geopolymer slurry have molar ratios $\mathrm{SiO}_{2} / \mathrm{Al}_{2} \mathrm{O}_{3}=5.26, \mathrm{Na}_{2} \mathrm{O} / \mathrm{SiO}_{2}=0.48$ and $\mathrm{H}_{2} \mathrm{O} / \mathrm{Na}_{2} \mathrm{O}=6.98$ and FA-based geopolymer slurry, molar ratios $\mathrm{SiO}_{2} / \mathrm{Al}_{2} \mathrm{O}_{3}=5.42, \mathrm{Na}_{2} \mathrm{O} / \mathrm{SiO}_{2}=0.15$ and $\mathrm{H}_{2} \mathrm{O} / \mathrm{Na}_{2} \mathrm{O}=11.16$.

After it was mixed until homogeneous (about $1 \mathrm{~min}$.), the geopolymer slurry was cast into a plastic mould $(2 \times 2 \times 2 \mathrm{~cm})$, and then subjected to hydrothermal curing at $60{ }^{\circ} \mathrm{C}$ for $24 \mathrm{~h}$ until it achieved geopolymerization, and was then subjected to water-submerged curing at $25^{\circ} \mathrm{C}$ for another six days. The geopolymer samples were then dried in oven at $100{ }^{\circ} \mathrm{C}$ for $24 \mathrm{~h}$, cooled, ground, sieved $(150 \mu \mathrm{m}$ ASTM E11-95 [40]), and labelled as GS (BFS-based geopolymer) and GA (FA-based geopolymer).

\subsection{Microstructure Analysis}

Materials crystallinity was determined by X-Ray diffraction (XRD) while using a Bruker D8 Advanced diffractometer (Centro de Investigación en Materiales Avanzados S.C.(CIMAV), Chihuahua, Chih., México). XRD analysis was performed in the $2 \theta$ range of $15^{\circ}$ to $70^{\circ}$ in order to verify the change from the crystalline phases of the raw materials to geopolymers. Fourier transform infrared spectroscopy (FTIR) was carried out using tablets mixed with $\mathrm{KBr}$ in a Bruker spectrophotometer 
model ATR Tensor 27 and the analysis was carried out in the frequency range of $4000-400 \mathrm{~cm}^{-1}$ to identify the functional groups of BFS, GS, FA, and GA. Peak deconvolution using Gaussean peak fitting was performed.

For SEM observation, hardened samples fragments were coated with gold to obtain the necessary conductivity to acquire the secondary electron images, and to observe porosity, microcracks, and crystals that are present in geopolymer matrix. The geopolymer morphology was obtained by SEM while using a Hitachi SU3500 scanning electron microscope (Advanced Materials Research Center (CIMAV), Chihuahua, Chih. México), at 3000×, 7000× 13,000× and 30,000×.

The texture properties were measured by $\mathrm{N}_{2}$ adsorption via a Brunauer-Emmett-Teller (BET) method using a Quantachrome Autosorb automated gas sorption system.

\subsection{Cation Exchange Capacity (CEC)}

The materials cation exchange capacity was determined by the $\mathrm{Na}^{+}$ion saturation with $1.0 \mathrm{~N}$ sodium acetate $\left(\mathrm{CH}_{3} \mathrm{COONa}\right)$, and subsequently a $\mathrm{Na}^{+}$ion exchange by $\mathrm{NH}^{4+}$ with $1.0 \mathrm{~N}$ ammonia acetate $\left(\mathrm{CH}_{3} \mathrm{COONH}_{4}\right)$. The $\mathrm{CEC}$ was estimated by an equation following [41]:

$$
\operatorname{CIC}\left(\frac{m_{e q}}{100 g}\right)=\frac{\left[N a^{+}\right] V(100)}{m M W}
$$

where:

$\left[\mathrm{Na}^{+}\right]=\mathrm{Na}^{+}$concentration in exchangeable solution $(\mathrm{mg} / \mathrm{L})$

$V=$ Exchangeable solution volume (L)

$m=$ Mass

$M W=$ Molecular weight

\subsection{Batch Adsorption Operation}

Lead adsorption was investigated in batch tests at a constant temperature of $25^{\circ} \mathrm{C}$. The tests were carried out, as follows: $0.5 \mathrm{~g}$ of geopolymer sample was added to $40 \mathrm{~mL}$ of $\mathrm{Pb}^{2+}$ solution with a different initial concentration $(5,10,20,50,100,200$, and $500 \mathrm{mg} / \mathrm{L})$ at $\mathrm{pH}$ values that ranged from 2 to 8 for a period of time of six days.

For each test, the lead concentration was determined by atomic absorption spectroscopy (AAS), while using the atomic absorption spectrophotometer GBC Avantar 4324 (Universidad de Guanajuato, Gto., México), and calculating the uptake percentage using the following equation [4]:

$$
\% R=\frac{C_{0}-C_{\mathrm{e}}}{C_{0}} \times 100
$$

where:

$C_{0}=$ Initial concentration of heavy metal solution $(\mathrm{mg} / \mathrm{L})$

$C_{\mathrm{e}}=$ Remaining equilibrium or final concentration $(\mathrm{mg} / \mathrm{L})$

The adsorption amount was calculated using the following equation [42]:

$$
q=\frac{\left(C_{0}-C_{\mathrm{e}}\right) V}{m}
$$

where:

$V=$ Solution volume $(\mathrm{L})$

$m=$ Mass of adsorbent $(\mathrm{g})$

Thus, once the value of $q$ was obtained for each $C_{e}$ value, those values were correlated to the Langmuir-Freundlich [43] model and their adsorption isotherms were obtained. 


\section{Results and Discussion}

\subsection{Mineralogical Analyses}

Figure 1 presents the XRD pattern of BFS and GS. In the patterns, the main peak is located around $30^{\circ} 2 \theta$, which corresponds to Calcite $\left(\mathrm{CaCO}_{3}\right)$ and it is associated with a large amount of $\mathrm{CaO}$ in raw BFS and its interaction with $\mathrm{CO}_{2}$ in the environment. This phase constitutes most of the BFS and GS. The other carbonate found is magnesite $\left(\mathrm{MgCO}_{3}\right)$ around $33^{\circ} 2 \theta$ due to a small but significant amount of $\mathrm{MgO}$ in the raw material. Calcium is linked to $\mathrm{Si}$ and $\mathrm{Al}$, forming calcium aluminosilicate, also called gehelenite $\left(\mathrm{Ca}_{2} \mathrm{Al}(\mathrm{SiAl}) \mathrm{O}_{7}\right)$. Finally, a small peak around $27^{\circ} 2 \theta$ is attributed to Quartz $\left(\mathrm{SiO}_{2}\right)$. Because all of these phases appear in both BFS and GS, it is possible to note that the crystalline structure of the raw material did not completely dissolve during the geopolymerization process. However, it is possible to observe wide dispersion peaks and a hump between $25-40^{\circ} 2 \theta$ identifying the amorphous structure of several typical metallurgical slags [44] and synthetized geopolymers, like GS [39,45]. In GS, it can observe new phases calcium aluminosilicate hydrated gel (CASH), such as chabasite-Ca $\left(\mathrm{Al}_{3.6} \mathrm{Ca}_{1.76} \mathrm{H}_{19.74} \mathrm{O}_{33.87} \mathrm{Si}_{8.4}\right)$ and chantalite $\left(\mathrm{Al}_{2} \mathrm{CaH}_{4} \mathrm{O}_{8} \mathrm{Si}\right)$, with triclinic and tetragonal structures, respectively, as well as sodium aluminosilicate hydrated (NASH) gel in a phase, called Analcime $\left(\mathrm{Al}_{2} \mathrm{H}_{4} \mathrm{Na}_{1.862} \mathrm{O}_{13.667} \mathrm{Si}_{4}\right)$, with an isometric crystal structure [46].

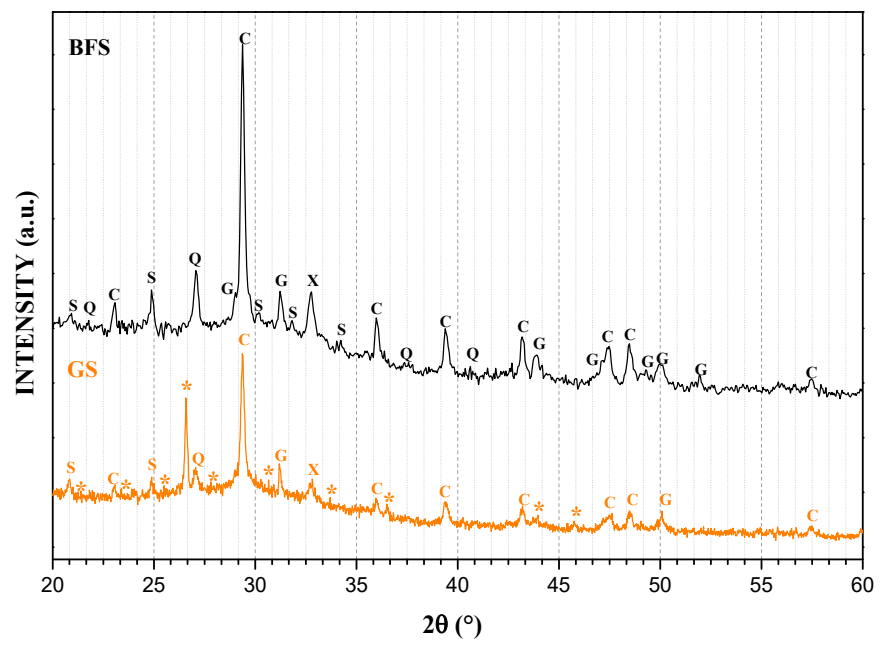

Figure 1. X-ray diffraction (XRD) patterns of blast furnace slag (BFS) and GS. $S=$ Calcium silicate, $\mathrm{Q}=$ Quartz, $\mathrm{C}=$ Calcite, $\mathrm{G}=$ Gehlenite $\mathrm{X}=$ Magnesite ${ }^{*}=$ calcium aluminosilicate hydrated (CASH) and sodium aluminosilicate hydrated (NASH) type gels.

On the other hand, Figure 2 presents the patterns of FA and GA. It is possible to observe that the FA is composed of quartz $\left(\mathrm{SiO}_{2}\right)$ corresponding to a peak around $27^{\circ} 2 \theta$ and mullite $\left(\mathrm{Al}_{6} \mathrm{Si}_{2} \mathrm{O}_{13}\right)$. After geopolymerization, the ions of these phases were redirected in an activated process and formed NASH-type gels, such as analcime $\left(\mathrm{Al}_{2} \mathrm{H}_{4} \mathrm{Na}_{1.862} \mathrm{O}_{13.667} \mathrm{Si}_{4}\right)$ and ussingite $\left(\mathrm{AlHNa}_{2} \mathrm{O}_{9} \mathrm{Si}_{3}\right)$, with orthorhombic and triclinic structure, respectively.

GS and GA both present phases that contain Al in their structure. This could indicate a greater number of exchange sites in the geopolymer, as the $\mathrm{Al}$ in the structure represents the sites where metal ions are exchanged for compensating ions in the solid matrix ( $\mathrm{Na}$ and $\mathrm{Ca}$ in this case). Table 2 summarizes the crystalline phases identified using XRD [47-51].

\subsection{Fourier Transform Infrared Spectroscopy (FT-IR)}

Figure 3 shows the spectra that were obtained for BFS and GS. In both spectrums, it can be observed the bands between 500 and $700 \mathrm{~cm}^{-1}$ associated with the vibrations of Si-O-Si or O-Si-O bonds, and both are attributed to Quartz. In raw material, there is a band at $541 \mathrm{~cm}^{-1}$, which was 
assigned to the symmetric stretches of the Si-O bonds, and the $710 \mathrm{~cm}^{-1}$ band is generated by in-plane bending vibrations of the same kind of bond, as well as the $690 \mathrm{~cm}^{-1}$ band in GS. Both types of vibration correspond to quartz [52].

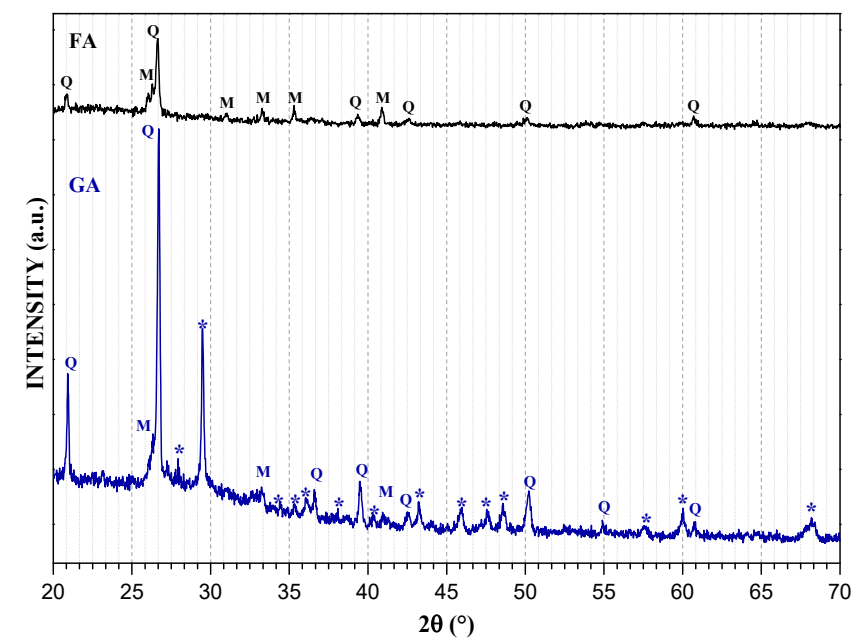

Figure 2. $\mathrm{XRD}$ patterns of FA and GA. $\mathrm{Q}=\mathrm{Quartz}, \mathrm{M}=$ Mullite, ${ }^{*}=\mathrm{NASH}$ type gels.

Table 2. Crystalline phases identified by XRD.

\begin{tabular}{cccc}
\hline Phase ID & Phase Name & Chemical Formula & ICDD-PDF ${ }^{\mathbf{1}}$ \\
\hline $\mathbf{C}$ & Calcite & $\mathrm{Ca}\left(\mathrm{CO}_{3}\right)$ & $00-001-0837$ \\
$\mathbf{S}$ & Calcium silicate & $\mathrm{Ca}_{2} \mathrm{SiO}_{4}$ & $00-072-2297$ \\
$\mathbf{G}$ & Calcium aluminosilicate & $\mathrm{Ca}_{2}\left(\mathrm{Al}(\mathrm{Al} \mathrm{Si}) \mathrm{O}_{7}\right.$ & $00-073-2041$ \\
$\mathbf{X}$ & (Gehlenite) & $\mathrm{MgCO}_{3}$ & $00-085-2348$ \\
$\mathbf{Q}$ & Magnesite & $\mathrm{SiO}_{2}$ & $00-046-1045$ \\
$\mathbf{M}$ & Quartz & $\mathrm{Al}_{6} \mathrm{Si}_{2} \mathrm{O}_{13}$ & $00-001-0613$ \\
$*$ & Mullite & & \\
& CASH and NASH gels & $\mathrm{Al}_{3.6} \mathrm{Ca}_{1.76} \mathrm{H}_{19.74} \mathrm{O}_{33.87} \mathrm{Si}_{8.4}$ & $96-901-4473$ \\
& Chabasite-Ca & $\mathrm{Al}_{2} \mathrm{CaH}_{4} \mathrm{O}_{8} \mathrm{Si}_{3}$ & $96-900-8283$ \\
& Chantalite & $\mathrm{Al}_{2} \mathrm{H}_{4} \mathrm{Na}_{1.862} \mathrm{O}_{13.667} \mathrm{Si}_{4}$ & $96-900-9956$ \\
& Analcime & $\mathrm{AlHNa}_{2} \mathrm{O}_{9} \mathrm{Si}_{3}$ & $96-901-6499$ \\
\hline
\end{tabular}

${ }^{1}$ ICDD-PDf International Centre for Diffraction data-Powder Diffraction File, ${ }^{*} \mathrm{CASH}$ and NASH identified phases.

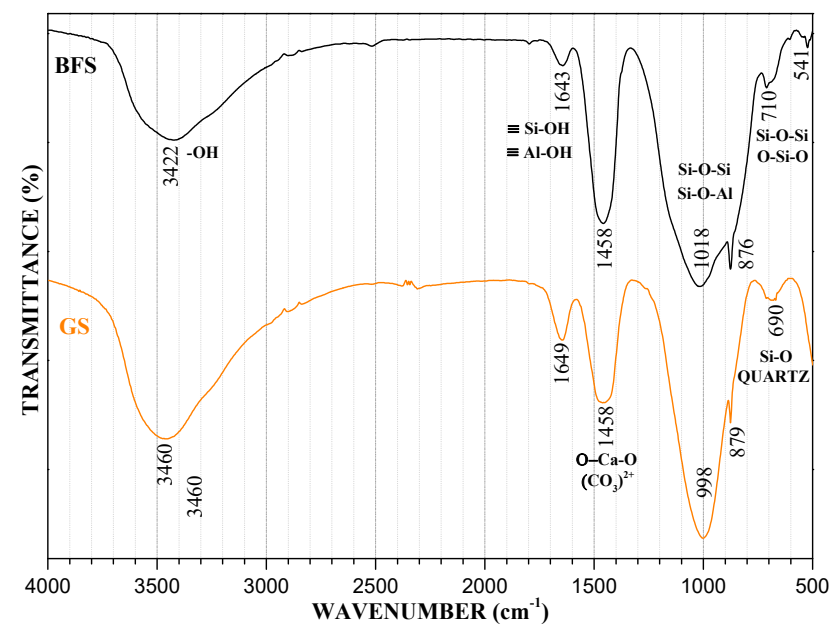

Figure 3. Fourier Transform Infrared Spectroscopy (FT-IR) spectrum of BFS and GE. 
The aluminosilicate characteristic band is located around $1000 \mathrm{~cm}^{-1}$. This band indicates asymmetric stretches on the $\mathrm{Si}-\mathrm{O}-\mathrm{Si}$ or $\mathrm{Si}-\mathrm{O}-\mathrm{Al}$ bonds of unreacted raw material. In BFS, it is situated at $1018 \mathrm{~cm}^{-1}$ and, in GS, it is displaced to $998 \mathrm{~cm}^{-1}$. This behavior is because a three-dimensional network of $\mathrm{Si}-\mathrm{O}$ bonds has not been well formed, as the glassy structure of the BFS is enriched with Ca and a large amount of this element is present at early ages in the solution. It consumes the Si and Al units, as they react preferentially with $\mathrm{Ca}$ to form a CASH gel instead of accumulating continuously. Figure 4 represents the deconvolution analysis of BFS and GS and shows the changes of molecular vibration that were present in the aluminosilicate characteristic band. The amorphous structure and the BFS intermolecular bonds produce more bands that together form a broad band. GS forms a tight band instead. In addition, because the position of this band depends on the Si/Al ratio of the product formed, the band moves at lower frequencies due to the rise in the tetrahedral aluminum content [51,53-59]. The replacement of $\mathrm{Si}^{4+}$ by $\mathrm{Al}^{3+}$ results in the $\mathrm{T}-\mathrm{O}-\mathrm{T}(\mathrm{T}=\mathrm{Si}$ or $\mathrm{Al})$ angle becoming more acute, and the band changing to lower frequencies because the Al-O bond is longer than the Si-O bond. The degree of substitution of the $\mathrm{Si}$ atoms by $\mathrm{Al}$ atoms has an important effect in the direction of the displacement of this band. On the other hand, bands located at wavenumbers $876 \mathrm{~cm}^{-1}$ in the raw material and at $879 \mathrm{~cm}^{-1}$ in GS may be attributed to the vibration in non-bridging oxygen bonds with Si-O-M $\left(\mathrm{M}=\mathrm{Na}^{+}, \mathrm{Ca}^{2+}\right) . \mathrm{Na}^{+}$ions are produced by the alkali activator $\left(\mathrm{NaOH}+\mathrm{Na}_{2} \mathrm{O}_{3} \mathrm{Si}\right)$, and the $\mathrm{Ca}^{2+}$ ions are produced by the main component in BFS $\left(\mathrm{CaCO}_{3}\right)$. These two ions are the interchangeable ions in the geopolymer. They may be released from the structure and leave a space for the metal ion $\left(\mathrm{Pb}^{2+}\right)$, whereby its presence is essential to the efficiency of the ion exchange mechanism [60-62].
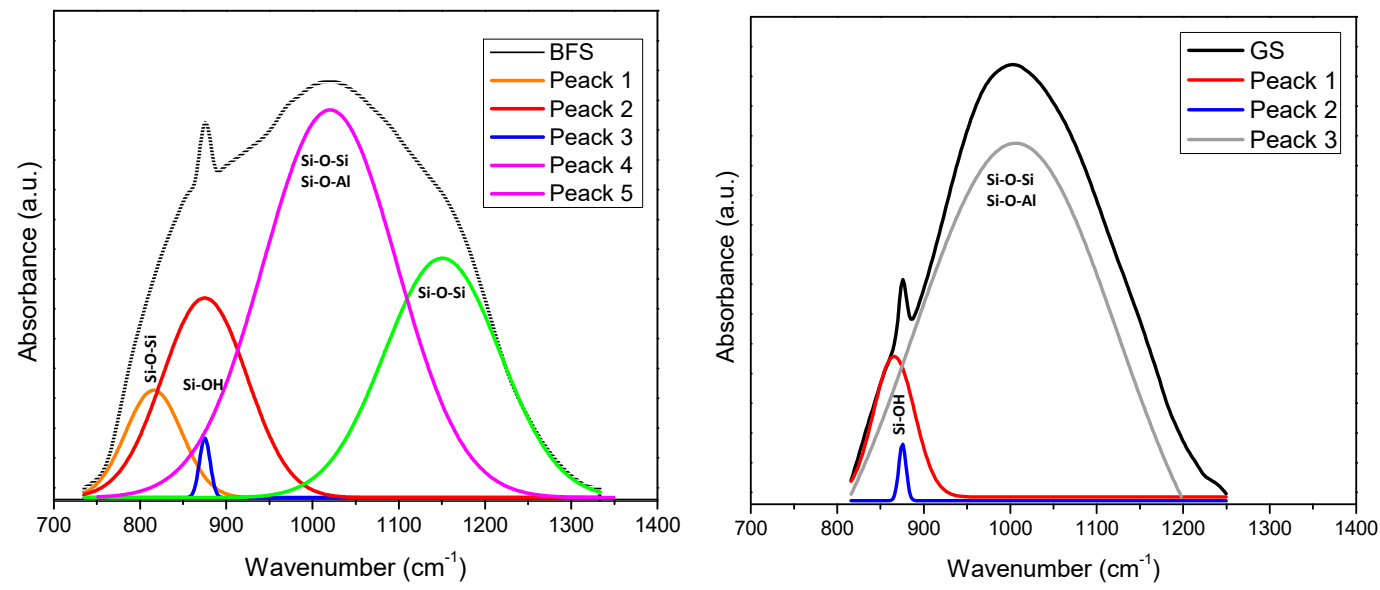

Figure 4. FT-IR Spectrum deconvolution of Si-O-T bands of BFS and GS.

On the other hand, there is a band at $1458 \mathrm{~cm}^{-1}$ in BFS and GS. This band corresponds to asymmetric stretches on the O-C-O bonds belonging to the $\mathrm{CO}_{3}{ }^{2-}$ groups $[51,63]$. Finally, bands corresponding to $\mathrm{O}-\mathrm{H}$ groups of chemically and physically bound water appear both in the GS and in the BFS. Water is necessary in the geopolymerization process, because it implies the dissolution of solid particles and $\mathrm{Al}^{3+}$ and $\mathrm{Si}^{4+}$ hydrolysis. The bands that are located at $1643 \mathrm{~cm}^{-1}$ in BFS and at $1649 \mathrm{~cm}^{-1}$ in GS are owing to vibrations in the weak bonds of silanol $(\equiv \mathrm{Si}-\mathrm{OH})$ and aluminol $(\equiv \mathrm{Al}-\mathrm{OH})$ of the physically bound water linked to the surface, and cavities in the structure of the geopolymer. Following this, a broad band around $3460 \mathrm{~cm}^{-1}$ in GS and $3422 \mathrm{~cm}^{-1}$ in BFS are attributed to stretching vibrations in the $\mathrm{O}-\mathrm{H}$ bonds of the hydroxyl groups of the chemically bound water in the material [37].

Figure 5 presents FA and GA spectra. It can be observed that the first bands are located around 650 and $688 \mathrm{~cm}^{-1}$. These bands correspond to vibrations of Si-O-Si and O-Si-O bonds and they are attributed to Mullite phase. Subsequently, FA presents a band around $788 \mathrm{~cm}^{-1}$ corresponding to Quartz Si-O bonds. Mullite bonds bands do not appear in GA, which suggests that the Mullite phase ions were redirected to form reaction gels. Conversely, the bands between 700 and $800 \mathrm{~cm}^{-1}$ in GA are attributed to the Quartz of the raw material. Aluminosilicate characteristic bands appear in FA around 
$1076 \mathrm{~cm}^{-1}$ and around $1007 \mathrm{~cm}^{-1}$ in GA. In addition to the BFS-based geopolymers, we can observe a small but important displacement to a lower signal in the deconvolution study in Figure 6. FA presents different bands that, just like BFS, could indicate the Si-O-Si or Si-O-Al bonds in aluminosilicate phases; once the geopolymerization is carried out, the number of bans decreases and GS and GA show a broad band instead, which may indicate that the Si-O-Si or Si-O-Al bonds correspond to amorphous NASH and CASH gel phases. The case of GA indicates that the $\mathrm{Si}$ and $\mathrm{Al}$ units were consumed by a high amount of $\mathrm{Na}$, contributed by alkali activator, in order to form NASH type gel.

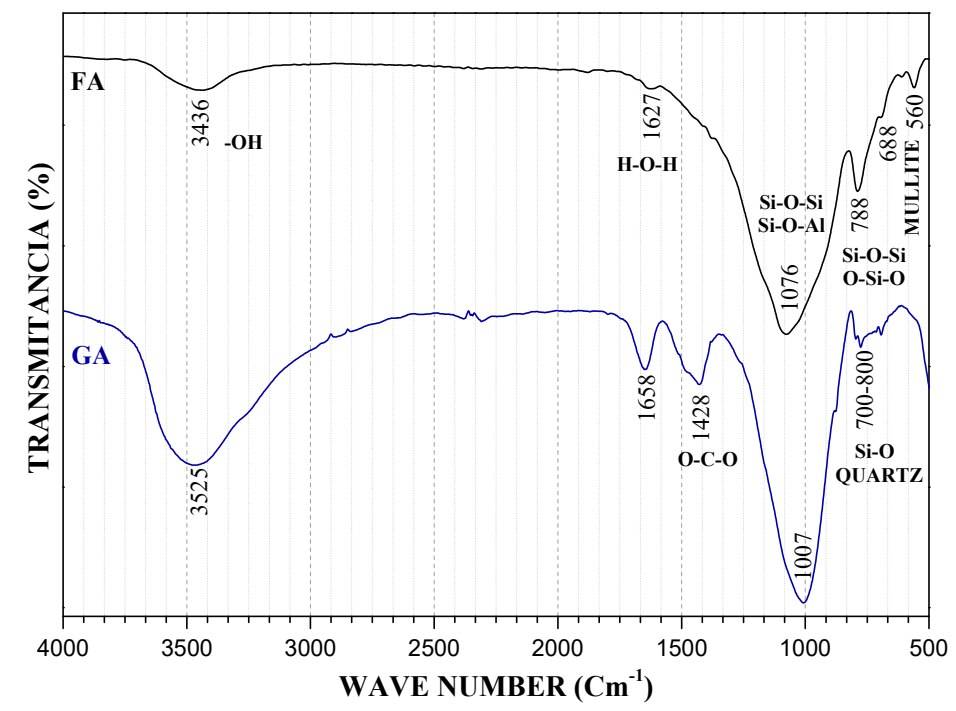

Figure 5. FT-IR spectrum of FA and GA.
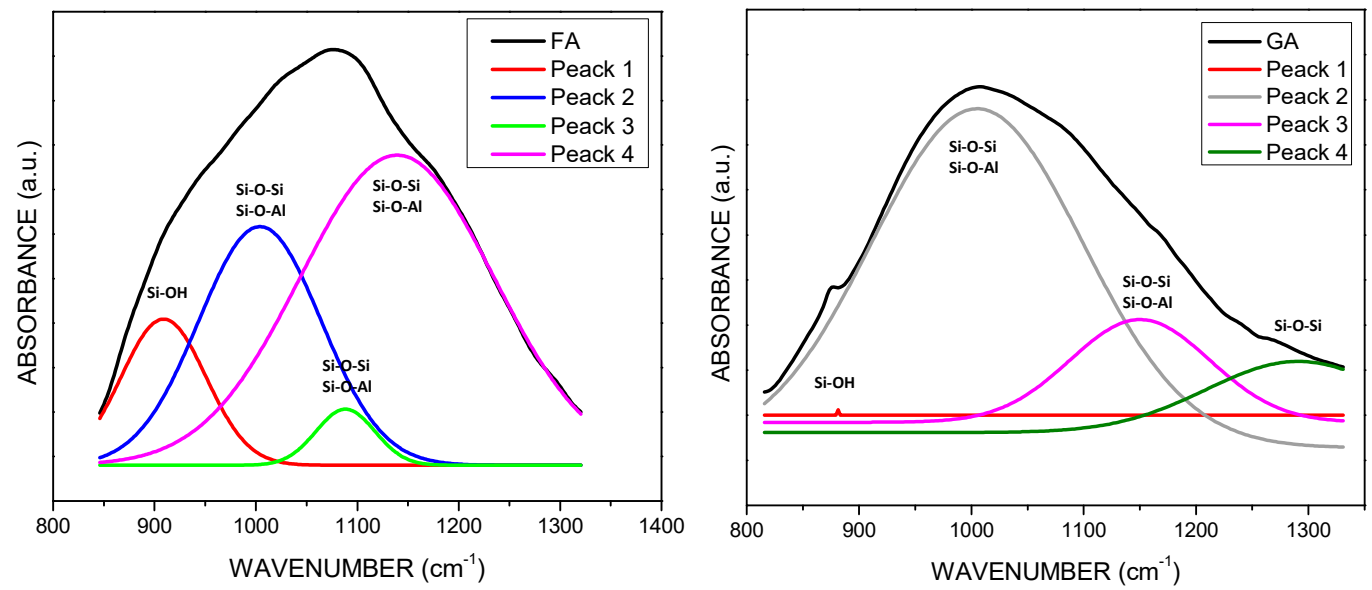

Figure 6. FT-IR Spectrum deconvolution of Si-O-T bands of FA and GA.

However, the atmospheric carbonation band is located in GA $1428 \mathrm{~cm}^{-1}$. This band is caused by vibrations in the $\mathrm{O}-\mathrm{C}-\mathrm{O}$ bonds and it indicates the presence of sodium bicarbonate in the samples. Finally, the bands caused by vibration in $\mathrm{H}-\mathrm{O}-\mathrm{H}$ and $-\mathrm{OH}$ bonds were also present in the geopolymers in the raw material. This bands corresponds to physically and chemically bonded water the same as occurs in GA. After geopolymerization, this band becomes broader, which is possibly due to an increase in water molecules by the hydrolysis process effect.

In general, it is possible to observe in all materials that the most intense band corresponds to the asymmetric stresses of Si-O-Si or Al-O-Al bonds. This is because BFS and FA mainly conform to aluminosilicates. In the BFS case, the main component is $\mathrm{CaO}$ in $\mathrm{CaCO}_{3}$ form. For this reason, the carbonates band (around $1400 \mathrm{~cm}^{-1}$ ) is more intense in BFS than in FA. 


\subsection{Scanning Electron Microscopy (SEM)}

Figure 7 shows SEM images for GS. In images " $a$ " and "b," we can observe a predominantly spherical shape with a smooth surface. This is the typical morphology of BFS after grinding with a rotating ball mill. The slag is composed of crystalline phases and, during the grinding, the bonds between the molecules and atoms are broken, thus leaving the shape of the surface broken [64]. The BFS grains are covered with amorphous and irregular structures. In image " $c$ ", it is possible to distinguish unreacted calcite grains, covered by amorphous CASH type gels. At last, in image d, irregular phases can be found, but with defined orthorhombic type forms, which can be attributed to the Analcime phase that is found in XRD studies. Analcime has relatively structured unit cells that are based on non-intersecting channels with four, six, and eight members of oxygen rings, and 16 sites occupied by sodium in the smallest 24 cavities, and by water molecules located in the 16 largest channels [46].
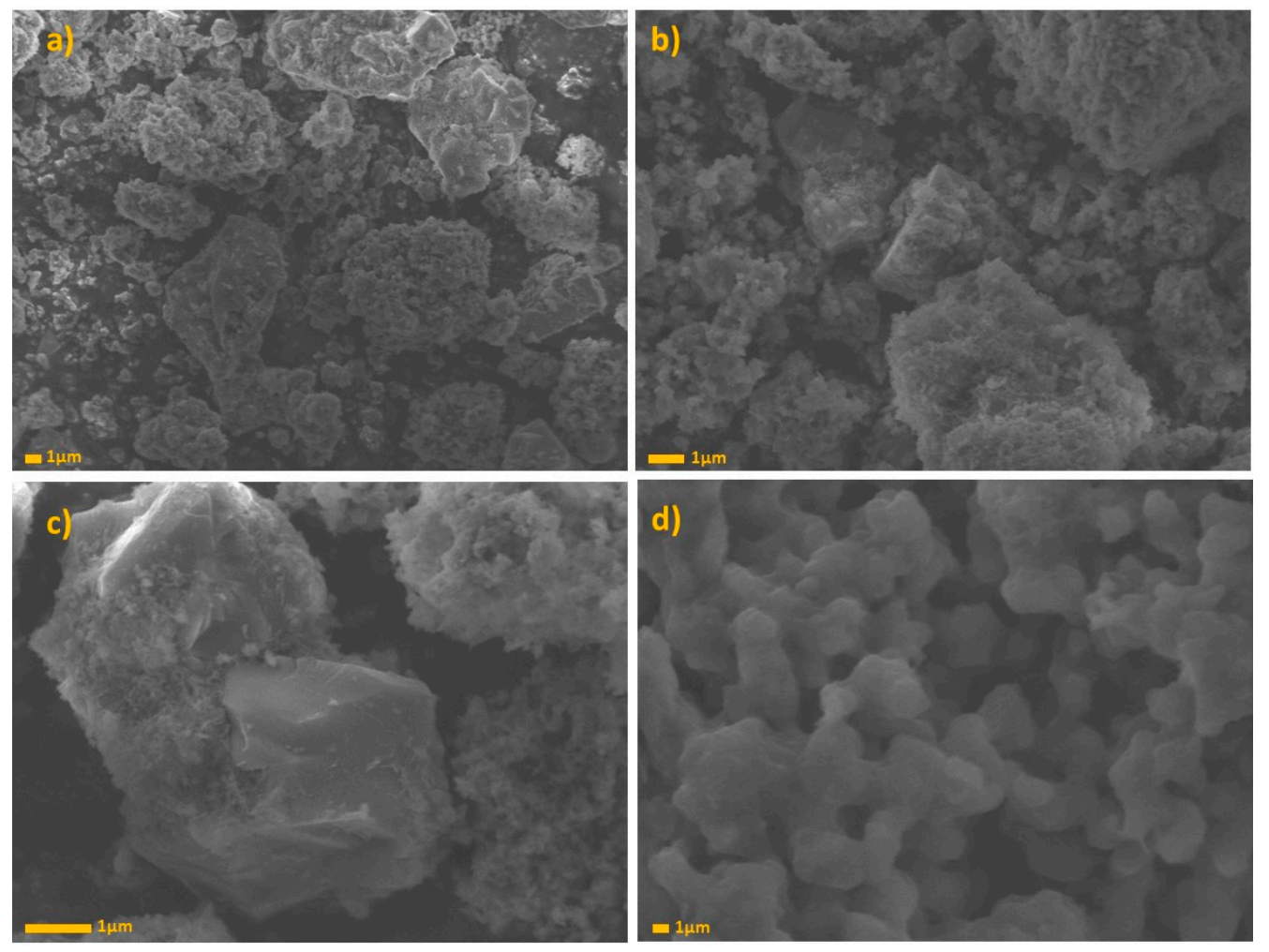

Figure 7. GS SEM images at (a) 3000×, (b) $7000 \times$, (c) 13,000×, and (d) 30,000×.

Thus, we can prove that the geopolymer is formed by crystalline, semi-crystalline, and amorphous phases; generally, the percentages of unreacted BFS covered by geopolymerization products, which will be in charge of giving the material the ion exchange property [65].

Figure 8 shows the SEM images for GA, by imaging that it is possible to observe irregular and amorphous structures, which are attributed to the reaction products obtained after geopolymerization (NASH type gels). In this image, it is possible to appreciate a hollow sphere shape, which is characteristic of FA structure. However, not many of these shapes are observed that can indicate a high reactivity of raw material. In image " $b$ ", the semi-spherical particles completely surrounded by the reaction product and NASH type gels. In image " $c$ " and " $\mathrm{d}$ ", we can observe irregular particles with triclinic structure. This structure is attributed to the ussignite phase [66]. 

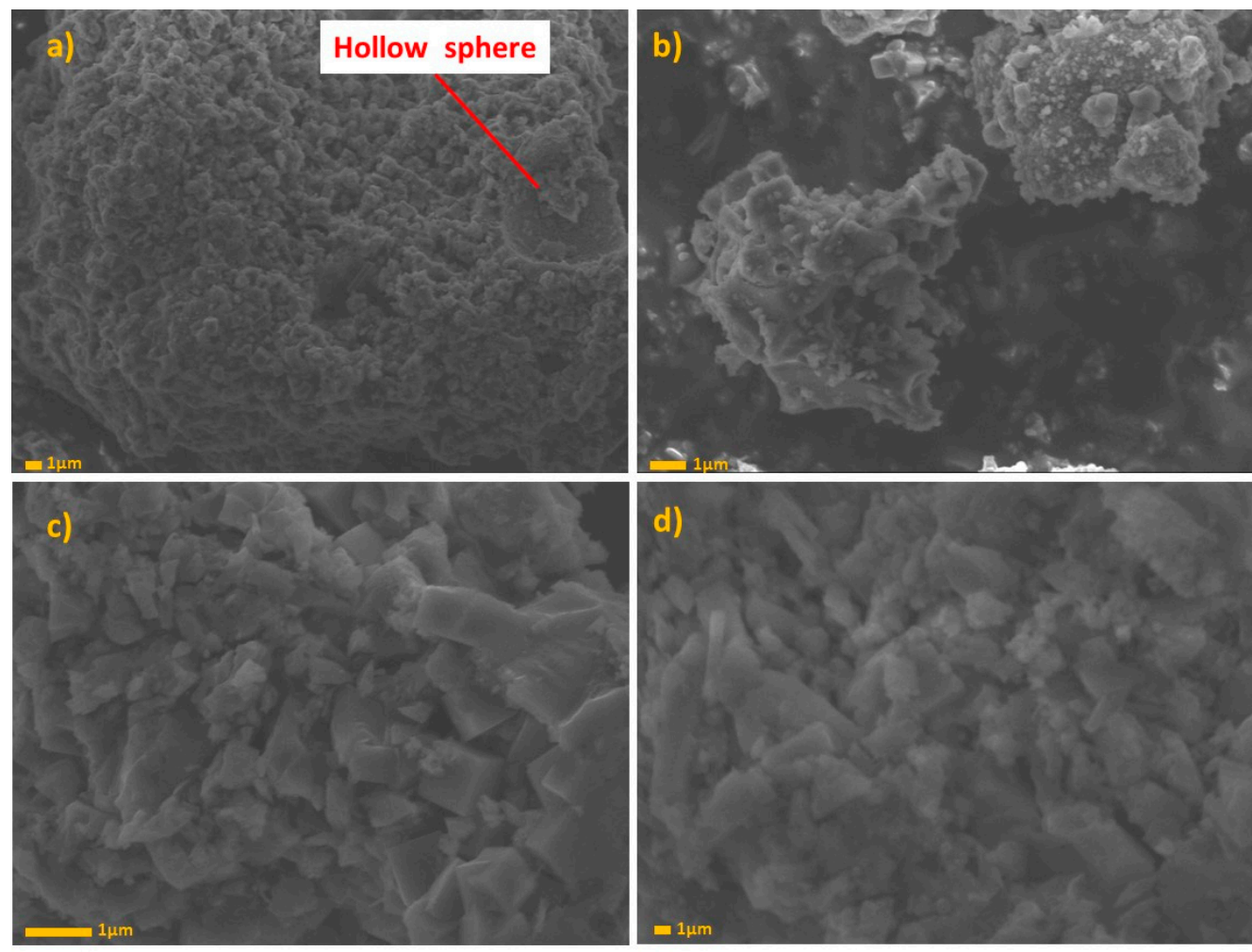

Figure 8. GA SEM images at (a) $3000 \times$ (b) $7000 \times$, (c) $13,000 \times$, and (d) $30,000 \times$.

\subsection{Physical Adsorption of Gases by the BET Method}

The specific surface of GS is $23.56 \mathrm{~m}^{2} / \mathrm{g}$ and the pore volume and size were $73 \mathrm{~cm}^{3} / \mathrm{kg}$ and $7.8 \mathrm{~nm}$, respectively, surpassing by about 26-fold the surface of the raw FA. By about 13 -fold the surface of the raw BFS. In the case of GA, the specific surface was $35.97 \mathrm{~m}^{2} / \mathrm{g}$ and the pore volume and size were $124 \mathrm{~cm}^{3} / \mathrm{Kg}$ and $9 \mathrm{~nm}$, respectively, surpassing by about 26 -fold the surface of the raw FA.

The increase in specific surface with respect to raw material corresponds to an addition of aluminum for adjusting the $\mathrm{Si} / \mathrm{Al}$ ratio of 3 , and also corresponds to the grinding process after geopolymerization. It favors the adsorption mechanism, as there is an increase in exchange sites in the geopolymer.

\subsection{CEC}

CEC depends on the number of available exchange sites in the geopolymer. According to the experimental results, GS and GA have an exchange capacity of 241.30 and $286.96 \mathrm{M}_{\mathrm{eq}} / 100 \mathrm{~g}$, respectively. In the DRX and MEB results, it was observed that the generation of phases, such as Analcime, Chantalite, Chabasite-Ca, and Ussignite, which had a high aluminium content, promoted the generation of a large number of exchange sites, and, hence, favored the adsorption capacity of the geopolymer.

\subsection{Adsorption Potential for $\mathrm{Pb}^{2+}$ Ions}

FA and BFS, according to Nguyen et al., can adsorb for itself positive metal ions by Coulombic forces on negatively charged particles at $\mathrm{pH}$ above 3 in FA and above $\mathrm{pH} 6$ in BFS; it is important to mention that the $\mathrm{pH}_{\mathrm{PZC}}$ of each of these materials is 3 and 6, respectively; however, adsorption by other forces can occur at all pHs independent of the PZC [67], it is possible that this mechanism occurs in geopolymers due to the presence of unreacted phases, like quartz, in the particles. The attractive forces of positively charged metal ions into GA and GS are due to relatively weak Van Der Waals forces and at active sites due to ion exchange of $\mathrm{Ca}^{+}$and $\mathrm{Na}^{+}$ions that are present in the geopolymer 
structure. The high specific surface area due to the porosity of GA and GS and volume pore are factors influencing the adsorption capacity [68].

Figure 9 shows the adsorption test data at 2, 4,6, and $8 \mathrm{pH}$. The maximum removal of lead (approximately $95 \%$ in GS and 99\% in GA) was reached at a $\mathrm{pH}$ of 6, and it decreased at a $\mathrm{pH}$ of 8 . According to the lead speciation graph, from about $6 \mathrm{pH}$, hydroxide species are formed, which cause precipitation on the geopolymer surface and block access to geopolymer pores for lead ions.

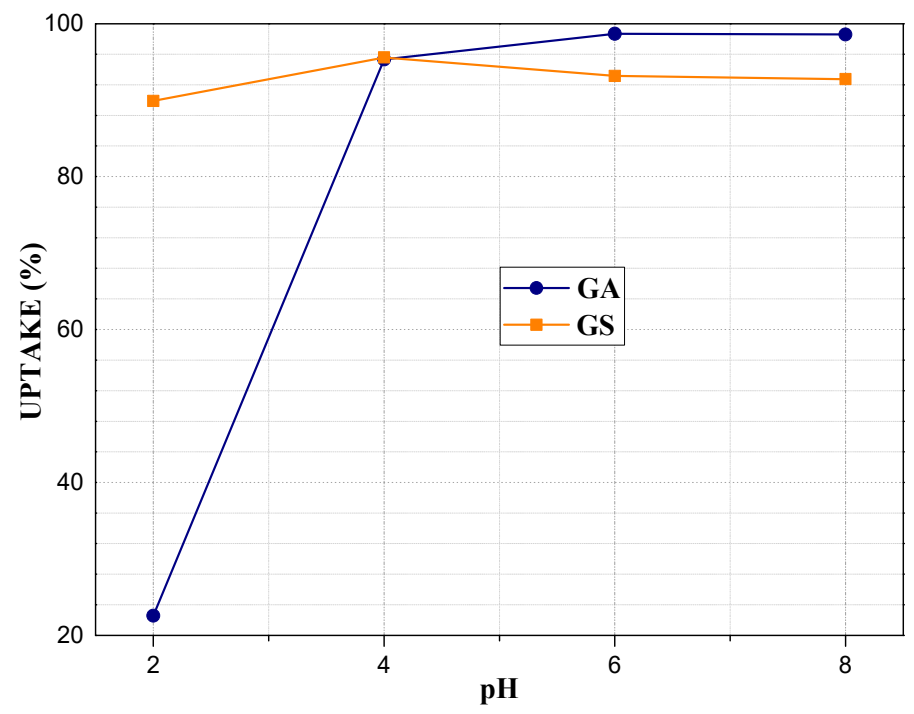

Figure 9. Influence of $\mathrm{pH}$ on geopolymers adsorption capacity of $\mathrm{Pb}^{2+}: \mathrm{m}=0.15 \mathrm{~g}, \mathrm{~V}=40 \mathrm{~mL}, \mathrm{C}_{0}=5 \mathrm{mg} / \mathrm{L}$.

At a $\mathrm{pH}$ of 2 and 4 , lead is in the ionized form in solution, and this allows access through the pores and, therefore, access to exchange sites by Van Der Waals forces, which indicates that geopolymers enhance their adsorption capacity in acidic media [69]. Figure 10 shows the effect of the initial $\mathrm{Pb}^{2+}$ concentration $\left(\mathrm{C}_{0}\right)$ on geopolymer adsorption capacity. In GS, adsorption capacities that are greater than $90 \%$ are obtained up to $100 \mathrm{mg} / \mathrm{L}$ concentration, due to the high CEC and porosity caused by aluminium-rich phases (analcime, chantalite, and chabasite-Ca). At $5 \mathrm{mg} / \mathrm{L}$ concentration, a removal of $95 \%$ is reached, which increases to $99.9 \%$ at $20 \mathrm{mg} / \mathrm{L}$. Subsequently, as the concentration increases, the removal percentage decreases by $20 \%$. In GA, the uptake increases to $10 \mathrm{mg} / \mathrm{L}$, reaching approximately $98 \%$. At 20 and $50 \mathrm{mg} / \mathrm{L}$, there is a decrease, and at 100, 200, and 500, an increase. The uptake obtained at 20 and 50 are inconsistent, probably due to an error in the $\mathrm{pH}$ adjustment [42].

\subsection{Langmuir-Freundlich Adsorption Isotherm}

The equilibrium isotherm shows the quantity of adsorbate $\left(\mathrm{Pb}^{2+}\right)$ that can be adsorbed by the adsorbent (GS and GA) in proportion to the equilibrium concentration in liquid phase. Furthermore, the equilibrium curve helps to explain certain phenomena that are associated with the adsorbate-adsorbent interaction [42,70]. The initial equilibrium curve shape of GS (Figure 11) and GA (Figure 12) have been identified as the L2 and S1 types, respectively, according to the Giles classification [71], and the best mathematical model that represents GS is the Langmuir model, and the Freundlich model for GA. In this study, the equilibrium isotherm used was the Langmuir-Freundlich $\left(R^{2}=0.992, G S\right.$ and $\left.R^{2}=9544, G A\right)$. The L-type shape indicates that the higher the concentration, the greater the adsorption amount until the available exchangeable sites reach their limit. Thereby, there is a competition between the metal ions for the available sites, and this kind of isotherm indicates that adsorption occurs because relatively weak forces as Van Der Waals. In the subclass 2 curves, there is no intermolecular interaction between the solute, which forms a long plateau that is represented by the maximum adsorption capacity $\left(\mathrm{q}_{\mathrm{m}}\right)$, indicating a saturation of the adsorbent monolayer before the additional adsorption at new sites, and the process becomes highly favorable, this $\mathrm{Pb}^{2+}$ adsorption 
in geopolymers based FA was reported by Al-Zboon et.al [72]. A high energy barrier is necessary, and this indicates that $\mathrm{q}_{\mathrm{m}}$ depicts the maximum number of exchangeable sites, in this case, $38.20 \mathrm{mg} / \mathrm{g}$. The S-type shape shows the opposite behavior to the L-type, because the orientation tends to be vertical for solute molecules at higher concentrations, and more sites are available for adsorption, which agreed with the CEC results. Subclass 1 of an S-type isotherm indicates completely vertical behavior of adsorption capacity, which is possibly caused by the precipitation of the solute on the adsorbent surface causing the curve slope to increase [46]. GA has a $\mathrm{q}_{\mathrm{m}}$ of $83.20 \mathrm{mg} / \mathrm{g}$, according to the Langmuir-Freundlich model.

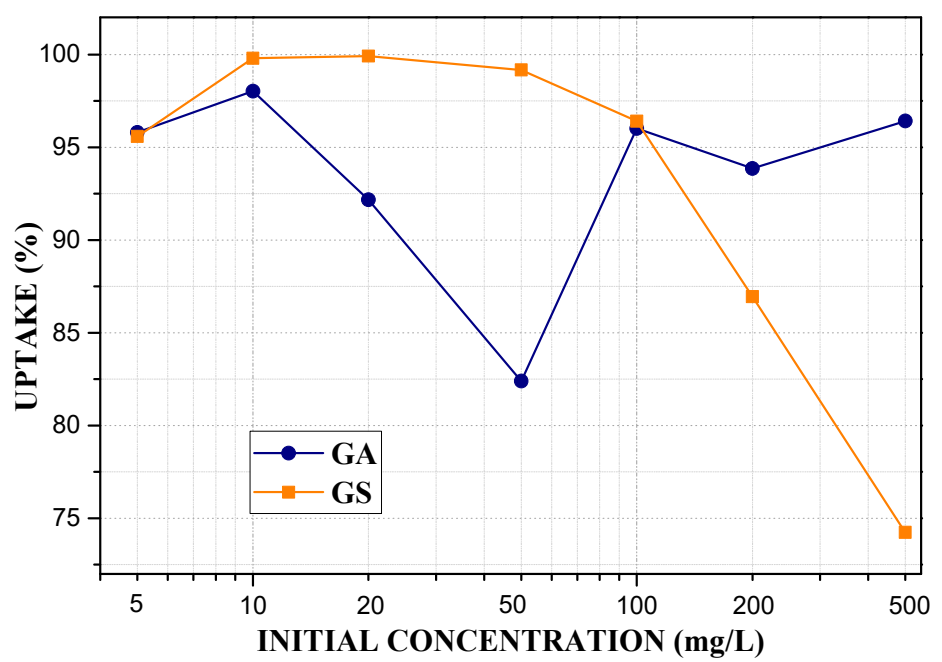

Figure 10. Influence of initial concentration on geopolymers adsorption capacity of $\mathrm{Pb}^{2+}: \mathrm{m}=0.15 \mathrm{~g}$, $\mathrm{V}=40 \mathrm{~mL}, \mathrm{pH}=4$.

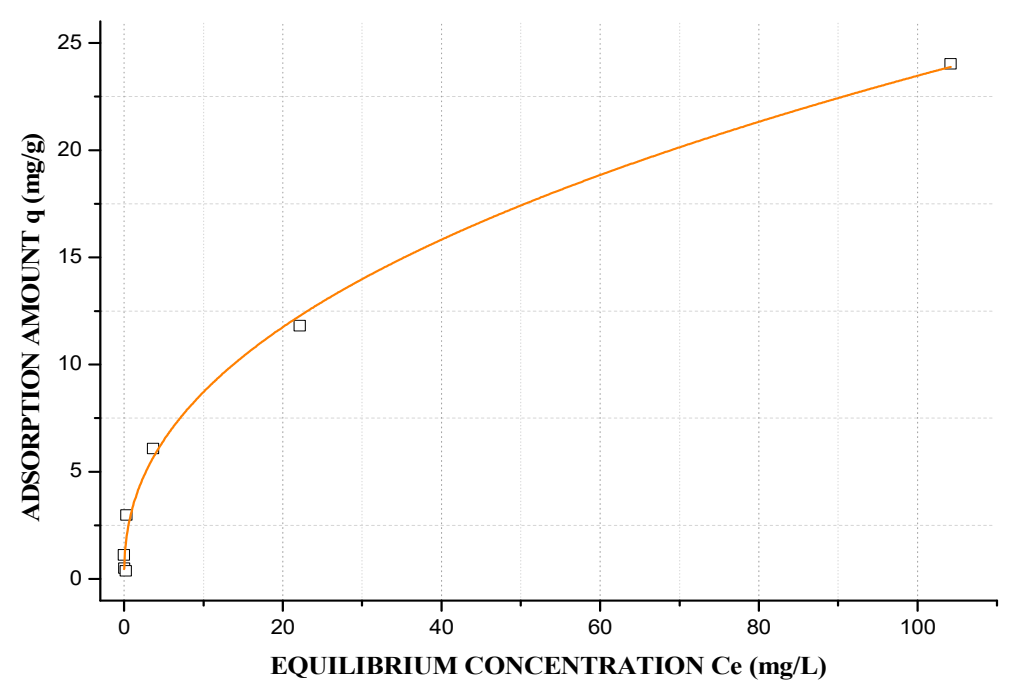

Figure 11. Langmuir-Freundlich Adsorption isotherm of GS: $\mathrm{m}=0.15 \mathrm{~g}, \mathrm{~V}=40 \mathrm{~mL}, \mathrm{pH}=4$. 


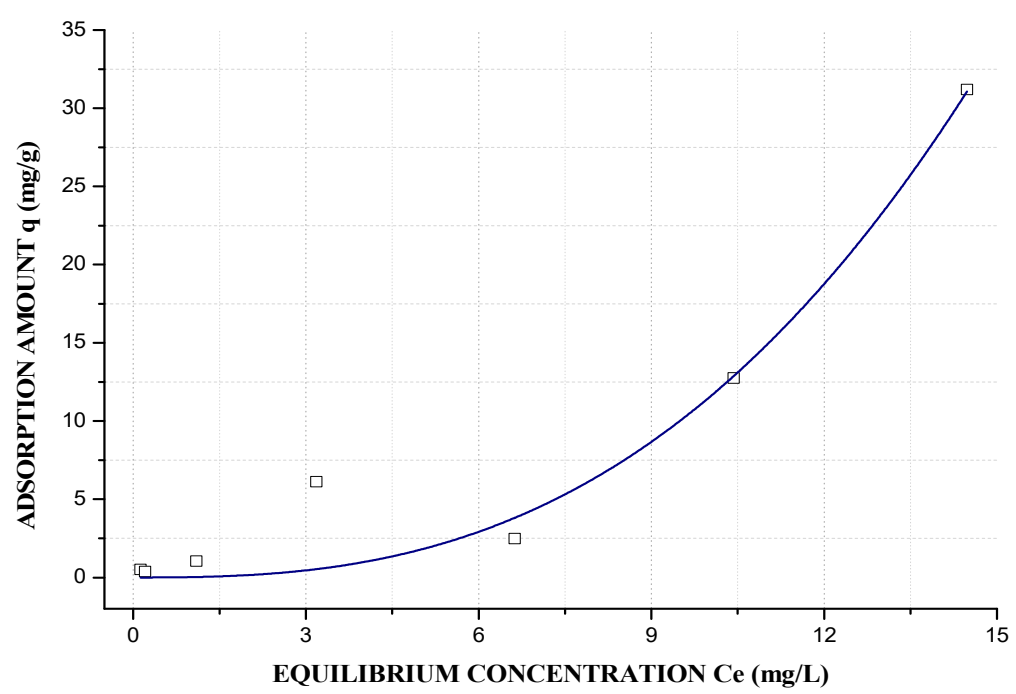

Figure 12. Langmuir-Freundlich Adsorption isotherm of GA: $\mathrm{m}=0.15 \mathrm{~g}, \mathrm{~V}=40 \mathrm{~mL}, \mathrm{pH}=4$.

\section{Conclusions}

GS and GA are comprised of crystalline, semi-crystalline, and amorphous phases.

The geopolymerization process generates $\mathrm{CASH}$ - and NASH-type gels, which are driven by high $\mathrm{Ca}$ and $\mathrm{Na}$ content, thus generating active sites for the ion exchange process.

GA generates NASH type gels only, and it has higher amorphicity and, hence, a more specific surface, porosity, and CEC.

Adsorption isotherms accorded well with the Langmuir-Freundlich adsorption isotherm model, and the maximum adsorption capacities for GS and GA were 38.20 and $83.20 \mathrm{mg} / \mathrm{g}$, respectively.

Additionally, adsorption occurs because of the relatively weak Van Der Waals forces in the reaction, allegedly by the ion exchange of $\mathrm{Ca}^{+}$and $\mathrm{Na}^{+}$present in the geopolymer structure.

The $\mathrm{Pb}^{2+}$ adsorption is strongly affected by $\mathrm{pH}$; better adsorption is obtained when a solution with neutral $\mathrm{pH}$ is used at room temperature.

Author Contributions: Data curation, C.A.R.; Investigation, T.J.M., S.P.A. and A.J.; Software, C.A.R.; Supervision, S.P.A., R.C., A.J. and R.A.Z.; Visualization, F.G.C. and J.M.B.; Writing-original draft, T.J.M.; Writing-review \& editing, S.P.A. and R.C. All authors have read and agreed to the published version of the manuscript.

Funding: This research was funded by Fondo Sectorial de Investigación para la Educación SEP-CONACYT, grant number A1-S-15401 and the APC was funded by grant number A1-S-15401.

Acknowledgments: The authors thank to "Fondo Sectorial de Investigación para la Educación SEP-CONACYT, grant number A1-S-15401"; to Consejo Nacional de Ciencia y Tecnología (CONACYT) for its doctoral scholarship program, to Universidad Autónoma de Sinaloa (UAS), Universidad de Guanajuato, Centro de Investigación en Materiales Avanzados S.C. (CIMAV) and Centro de Investigaciones en Óptica A.C. (CIO), for the support and availability of resources and equipment.

Conflicts of Interest: The authors declare no conflict of interest.

\section{References}

1. De la Peña, M.E.; Ducci, J.; Zamora, V. Tratamiento de Aguas Residuales en México; IDB-TN-512; Banco Interamericano de Desarrollo: Washington, DC, USA, 2013; p. 42.

2. Cardona-Gutiérrez, A.F.; Cabañas-Vargas, D.D.; Zepeda-Pedreguera, A. Evaluación del poder biosorbente de cáscara de naranja para la eliminación de metales pesados, $\mathrm{Pb}$ (II) y Zn (II). Ingeniería 2013, 17, 1-9.

3. Bumanis, G.; Novais, R.M.; Carvalheiras, J.; Bajare, D.; Labrincha, J.A. Metals removal from aqueous solutions by tailored porous waste-based granulated alkali-activated materials. Appl. Clay Sci. 2019, 179, 105147. [CrossRef]

4. Onutai, S.; Kobayashi, T.; Thavorniti, P.; Jiemsirilers, S. Removal of $\mathrm{Pb}^{2+}, \mathrm{Cu}^{2+}, \mathrm{Ni}^{2+}, \mathrm{Cd}^{2+}$ from wastewater using fly ash based geopolymer as an adsorbent. Key Eng. Mater. 2018, 773, 373-378. [CrossRef] 
5. Obeng-Gyasi, E. Sources of lead exposure in various countries. Rev. Environ. Health 2019, 34, $25-34$. [CrossRef] [PubMed]

6. Dignam, T.; Kaufmann, R.B.; LeStourgeon, L.; Brown, M.J. Control of lead sources in the United States, 1970-2017: Public health progress and current challenges to eliminating lead exposure. Physiol. Behav. 2017, 176, 139-148. [CrossRef]

7. Fry, D.M.; Maurer, J.R. Assessment of Lead Contamination Sources Exposing California Condors; Species Conservation and Recovery Program report 2003-02; California Department of Fish and Game Habitat Conservation Planning Branch: Sacramento, CA, USA, 2003.

8. Huang, Z.Y.; Chen, T.; Yu, J.; Qin, D.P.; Chen, L. Lead contamination and its potential sources in vegetables and soils of Fujian, China. Environ. Geochem. Health 2012, 34, 55-65. [CrossRef]

9. Reyes, Y.C.; Vergara, I.; Torres, O.E.; Díaz, M.; González, E.E. Contaminación por metales pesados: Implicaciones en salud, ambiente y seguridad alimentaria. Rev. Ing. Investig. Y Desarro. 2016, 16, 77. [CrossRef]

10. Papanikolaou, N.C.; Hatzidaki, E.G.; Belivanis, S.; Tzanakakis, G.N.; Tsatsakis, A.M. Lead toxicity update. A brief review. Med. Sci. Monit. 2005, 11, 329-336.

11. Moreno-Rivas, S.C.; Ramos-Clamont Montfort, G. Descontaminación de arsénico, cadmio y plomo en agua por biosorción con Saccharomyces cerevisiae. TIP Rev. Espec. En Cienc. Quím. Biol. 2018, 21, 51. [CrossRef]

12. Mohod, C.V.; Dhote, J. Review of heavy metals in drinking water and their effect on human health. Int. J. Innov. Res. Sci. Eng. Technol. 2013, 2, 2992-2996.

13. Martin, S.; Griswold, W. Human health effects of heavy metals: Briefs for citizens. Environ. Sci. Technol. 2009, $15,1-6$.

14. Jan, A.T.; Azam, M.; Siddiqui, K.; Ali, A.; Choi, I.; Haq, Q.M.R. Heavy metals and human health: Mechanistic insight into toxicity and counter defense system of antioxidants. Int. J. Mol. Sci. 2015, 16, 29592-29630. [CrossRef] [PubMed]

15. Pérez Vázquez, R.G. Efecto de los Metales Pesados en la Salud Humana. Bachelor's Thesis, Universidad de Pinar del Río “Hermanos Saíz Montes de Oca”, Pinar del Río, Cuba, 2011.

16. Caviedes Rubio, D.I.; Muñoz Calderón, R.A.; Perdomo Gualtero, A.; Rodríguez Acosta, D.; Sandoval Rojas, I.J. Tratamientos para la remoción de metales pesados comúnmente presentes en aguas residuales industriales. Una revisión. Rev. Ing. Y Reg. 2015, 13, 73-90. [CrossRef]

17. Bapat, S.A.; Jaspal, D.K. Parthenium hysterophorus: Novel adsorbent for the removal of heavy metals and dyes. Glob. J. Environ. Sci. Manag. 2016, 2, 135-144. [CrossRef]

18. Matlock, M.M.; Howerton, B.S.; Atwood, D.A. Chemical precipitation of heavy metals from acid mine drainage. Water Res. 2002, 36, 4757-4764. [CrossRef]

19. Efome, J.E.; Rana, D.; Matsuura, T.; Lan, C.Q. Effects of operating parameters and coexisting ions on the efficiency of heavy metal ions removal by nano-fibrous metal-organic framework membrane filtration process. Sci. Total Environ. 2019, 674, 355-362. [CrossRef]

20. Fu, F.; Wang, Q. Removal of heavy metal ions from wastewaters: A review. J. Environ. Manag. 2011, 92, 407-418. [CrossRef]

21. Torres Gaviria, L.F.; Ocampo Vélez, J.C.; Socarrás Cárdenas, A. Reducción del nivel de potasio en vinaza de destilería utilizando resinas de intercambio iónico. Rev. Investig. Agrar. Y Ambient. 2018, 10, 107-118. [CrossRef]

22. Helfferich, F. Ion. Exchange; Hill, M., Ed.; Dover Publications, INC.: New York, NY, USA, 1995; ISBN 0-486-68784-8.

23. Nascimento, I.S.; Silva, D.L.; Pereira, T.B.; Gonzálves, G.R.F.; Veríssimo, L.A.A.; Veloso, C.M.; Bonomo, R.C.F.; Fontan, R.C.I. Capture of lectins from jackfruit (Artocarpus integrifolia) seeds in a single step using a supermacroporous ion exchange cryogel. Rev. Mex. Ing. Quim. 2019, 18, 313-324. [CrossRef]

24. López Guzmán, F.J. Study of Geopolymer Adsorbents Prepared from Metakaolin and Rice Husk Silica for Targeting to Heavy Metal Capture. Ph.D. Thesis, Nagaoka University of Technology, Nagaoka, Japan, 2014.

25. Yan, C.; Guo, L.; Ren, D.; Duan, P. Novel composites based on geopolymer for removal of Pb (II). Mater. Lett. 2018, 239, 192-195. [CrossRef]

26. Villaquirán-Caicedo, M.A.; Mejía de Gutiérrez, R. Synthesis of ceramic materials from ecofriendly geopolymer precursors. Mater. Lett. 2018, 230, 300-304. [CrossRef]

27. Davidovits, J. Geopolymers. J. Therm. Anal. 1991, 37, 1633-1656. [CrossRef] 
28. Provis, J.L.; Van Deventer, J.S.J. Introduction of Geopolymers. Geopolymers. Structure, Processing, Properties and Industrial Applications, 1st ed.; Provis, J.L., van Deventer, J.S., Eds.; Elsevier: Amsterdam, The Netherlands, 2009; ISBN 9781845694494.

29. Liew, Y.M.; Heah, C.Y.; Mohd Mustafa, A.B.; Kamarudin, H. Structure and properties of clay-based geopolymer cements: A review. Prog. Mater. Sci. 2016, 83, 595-629. [CrossRef]

30. Davidovits, J. Geopolymer. Chemistry \& Applications, 2nd ed.; Institut Geopolymere: Saint-Quentin, France, 2008; ISBN 2-9514820-1-9.

31. Kumar, S.; Kumar, R.; Mehrotra, S.P. Influence of granulated blast furnace slag on the reaction, structure and properties of fly ash based geopolymer. J. Mater. Sci. 2010, 45, 607-615. [CrossRef]

32. Özcan, A.; Karakoç, M.B. The resistance of blast furnace slag- and ferrochrome slag-based geopolymer concrete against acid attack. Int. J. Civ. Eng. 2019, 17. [CrossRef]

33. Luukkonen, T.; Heponiemi, A.; Runtti, H.; Pesonen, J.; Yliniemi, J.; Lassi, U. Application of alkali-activated materials for water and wastewater treatment: A review. Rev. Environ. Sci. Biotechnol. 2019, 18, 271-297. [CrossRef]

34. Jena, S.; Panigrahi, R.; Sahu, P. Effect of silica fume on the properties of fly ash geopolymer concrete. Lect. Notes Civ. Eng. 2019, 25, 145-153. [CrossRef]

35. Poltue, T.; Suddeepong, A.; Horpibulsuk, S.; Samingthong, W.; Arulrajah, A.; Rashid, A.S.A. Strength development of recycled concrete aggregate stabilized with fly ash-rice husk ash based geopolymer as pavement base material. Road Mater. Pavement Des. 2019, 1-12. [CrossRef]

36. Zhu, H.; Liang, G.; Xu, J.; Wu, Q.; Zhai, M. Influence of rice husk ash on the waterproof properties of ultrafine fly ash based geopolymer. Constr. Build. Mater. 2019, 208, 394-401. [CrossRef]

37. Siddique, R.; Khan, M.I. Supplementary Cementing Materials; Engineering Materials; Springer: Berlin/Heidelberg, Germany, 2011; Volume 37, ISBN 978-3-642-17865-8.

38. Riveros Olivares, B. Tratamiento de Aguas Residuales Municipales en la Ciudad de México. Bachelor's Thesis, Universidad Nacional Autónoma De México, Mexico City, Mexico, 2013.

39. Petrakis, E.; Karmali, V.; Bartzas, G.; Komnitsas, K. Grinding kinetics of slag and e ff ect of final particle size on the compressive strength of Alkali. Minerals 2019, 9, 714. [CrossRef]

40. ASTM International. Standard Specifications for Wire Cloth and Sieves for Testing Purposes; ASTM E11-95; ASTM International: West Conshohocken, PA, USA, 2001.

41. Leyva Ramos, R.; Medellín Castillo, N.A.; Guerrero Coronado, R.M.; Berber Mendoza, M.S.; Aragón Piña, A.; Jacobo Azuara, A. Intercambio iónico de Plata (I) en solución acuosa sobre clinoptilolita. Rev. Int. Contam. Ambient. 2005, 21, 193-200.

42. Bonilla-Petriciolet, A.; Mendoza-Castillo, D.I.; Reynel-Ávila, H.E. Adsorption Processes for Water Treatment and Puri Cation; Springer International Publishing: Cham, Switzerland, 2017; ISBN 9783319581354.

43. Jeppu, G.P.; Clement, T.P. A modified Langmuir-Freundlich isotherm model for simulating pH-dependent adsorption effects. J. Contam. Hydrol. 2012, 129-130, 46-53. [CrossRef] [PubMed]

44. Komnitsas, K.; Bartzas, G.; Karmali, V.; Petrakis, E.; Witold, K.; Grzegorz, P.; Jaroslaw, K. Assessment of alkali activation potential of a Polish Ferronickel slag. Sustainability 2019, 11, 1863. [CrossRef]

45. Zaharaki, D.; Komnitsas, K.; Perdikatsis, V. Use of analytical techniques for identification of inorganic polymer gel composition. J. Mater. Sci. 2010, 45, 2715-2724. [CrossRef]

46. Vigil de la Villa Mencía, R.; Goiti, E.; Ocejo, M.; García Giménez, R. Synthesis of zeolite type analcime from industrial wastes. Microporous Mesoporous Mater. 2019, 1-9. [CrossRef]

47. Siyal, A.A.; Shamsuddin, M.R.; Khan, M.I.; Rabat, N.E.; Zulfiqar, M.; Man, Z.; Siame, J.; Azizli, K.A. A review on geopolymers as emerging materials for the adsorption of heavy metals and dyes. J. Environ. Manag. 2018, 224, 327-339. [CrossRef]

48. Criado, M.; Fernández-Jiménez, A.; Palomo, A. Alkali activation of fly ash: Effect of the $\mathrm{SiO}_{2} / \mathrm{Na}_{2} \mathrm{O}$ ratio. Part I: FTIR study. Microporous Mesoporous Mater. 2007, 106, 180-191. [CrossRef]

49. Gadsden, J.A. Infrared Spectra of Minerals and Related Inorganic Compounds; Butterworths: London, UK, 1975; ISBN 0-408-70665-1.

50. Yousuf, M.; Mollah, A.; Hess, T.R.; Tsai, Y.N.; Cocke, D.L. An FTIR and XPS investigations of the effects of carbonation on the solidification/stabilization of cement based systems-Portland type V with zinc. Cem. Concr. Res. 1993, 23, 773-784. [CrossRef] 
51. Amin, M. Impact of alkali cations on properties of metakaolin and metakaolin/slag geopolymers: Microstructures in relation to sorption of 134 Cs radionuclide. J. Hazard. Mater. 2018, 344, 913-924. [CrossRef]

52. Kovtun, M.; Kearsley, E.P.; Shekhovtsova, J. Cement and Concrete Research Chemical acceleration of a neutral granulated blast-furnace slag activated by sodium carbonate. Cem. Concr. Res. 2015, 72, 1-9. [CrossRef]

53. Fernández-Jiménez, A.; Palomo, A. Mid-Infrared spectroscopic studies of alkali-activated fly ash structure. Microporous Mesoporous Mater. 2005, 86, 207-214. [CrossRef]

54. Torres-Carrasco, M.; Puertas, F. Waste glass in the geopolymer preparation. Mechanical and microstructural characterisation. J. Clean. Prod. 2015, 90, 397-408. [CrossRef]

55. Gao, X.; Yu, Q.L.; Brouwers, H.J.H. Reaction kinetics, gel character and strength of ambient temperature cured alkali activated slag-fly ash blends. Constr. Build. Mater. 2015, 80, 105-115. [CrossRef]

56. Wang, J.; Wu, X.L.; Wang, J.X.; Liu, C.Z.; Lai, Y.M.; Hong, Z.K.; Zheng, J.P. Hydrothermal synthesis and characterization of alkali-activated slag-fly ash-metakaolin cementitious materials. Microporous Mesoporous Mater. 2012, 155, 186-191. [CrossRef]

57. Zhang, Z.; Wang, H.; Provis, J.L.; Bullen, F.; Reid, A.; Zhu, Y. Quantitative kinetic and structural analysis of geopolymers. Part 1. the activation of metakaolin with sodium hydroxide. Thermochim. Acta 2012, 539, 23-33. [CrossRef]

58. Hajimohammadi, A.; Provis, J.L.; Van Deventer, J.S.J. Time-Resolved and spatially-resolved infrared spectroscopic observation of seeded nucleation controlling geopolymer gel formation. J. Colloid Interface Sci. 2011, 357, 384-392. [CrossRef] [PubMed]

59. Barbosa, T.R.; Foletto, E.L.; Dotto, G.L.; Jahn, S.L. Preparation of mesoporous geopolymer using metakaolin and rice husk ash as synthesis precursors and its use as potential adsorbent to remove organic dye from aqueous solutions. Ceram. Int. 2018, 44, 416-423. [CrossRef]

60. Pavia, D.L.; Lampman, G.M.; Kriz, G.S.; Vyvyan, J.R. Introduction to Spectroscopy, 4th ed.; Harcourt College Publishers: San Diego, CA, USA, 2009; ISBN 978-0-495-11478-9.

61. Albella, J.M.; Cintas, A.M.; Miranda, T.; Serratosa, J.M. Introducción a la Ciencia de Materiales. Técnicas de Preparación y Caracterización; Consejo Superior de Investigaciones Científicas: Madrid, Spain, 1993; ISBN 84-00-07343-6.

62. Bernal, S.A.; Provis, J.L.; Rose, V.; Mejía De Gutierrez, R. Evolution of binder structure in sodium silicate-activated slag-metakaolin blends. Cem. Concr. Compos. 2011, 33, 46-54. [CrossRef]

63. Yu, P.; Kirkpatrick, R.J.; Poe, B.; McMillan, P.F.; Cong, X. Structure of Calcium Silicate Hydrate (C-S-H): Near-, mid-, and far-infrared spectroscopy. J. Am. Ceram. Soc. 2004, 82, 742-748. [CrossRef]

64. Vereshchagina, T.A.; Kutikhina, E.A.; Solovyov, L.A.; Vereshchagin, S.N.; Mazurova, E.V.; Chernykh, Y.Y.; Anshits, A.G. Synthesis and structure of analcime and analcime-zirconia composite derived from coal fly ash cenospheres. Microporous Mesoporous Mater. 2018, 258, 228-235. [CrossRef]

65. Chen, Y.; Zhou, X.; Wan, S.; Zheng, R.; Tong, J.; Hou, H.; Wang, T. Synthesis and characterization of geopolymer composites based on gasification coal fly ash and steel slag. Constr. Build. Mater. 2019, 211, 646-658. [CrossRef]

66. Powell, K.J.; Brown, P.L.; Byrne, R.H.; Gajda, T.; Hefter, G.; Leuz, A.; Sjöberg, S.; Wanner, H. Chemical speciation of environmentally significant metals with inorganic ligands. Part 3: $\mathrm{The}^{2+}+\mathrm{OH}^{-}, \mathrm{Cl}^{-}, \mathrm{CO}_{3}{ }^{2-}$, $\mathrm{SO}_{4}{ }^{2-}$, and $\mathrm{PO}_{4}{ }^{3-}$ Systems (IUPAC technical report). Pure Appl. Chem. 2009, 81, 2425-2476. [CrossRef]

67. Nguyen, T.C.; Loganathan, P.; Nguyen, T.V.; Kandasamy, J.; Naidu, R.; Vigneswaran, S. Adsorptive removal of five heavy metals from water using blast furnace slag and fly ash. Environ. Sci. Pollut. Res. 2018, 25, 20430-20438. [CrossRef] [PubMed]

68. Komnitsas, K.; Zaharaki, D.; Bartzas, G.; Alevios, G. Adsorption of Scandium and Neodymium on Biochar derived after low-temperature pyrolysis of sawdust. Minerals 2017, 7, 200. [CrossRef]

69. Alshaaer, M.; Zaharaki, D.; Komnitsas, K. Microstructural characteristics and adsorption potential of a zeolitic tuff-metakaolin geopolymer. Desalin. Water Treat. 2015, 56, 338-345. [CrossRef]

70. García Aseno, N. Una Nueva Generación de Carbones Activados de Altas Prestaciones Para Aplicaciones Medioambientales. Ph.D. Thesis, Universidad de Oviedo, Oviedo, Spain, 2014. 
71. Giles, C.H.; MacEwan, T.H.; Nakhwa, S.N.; Smith, D. Studies in adsorption. Part XI. A system of classification of solution adsorption isotherms and its use in diagnosis of adsorption mechanisms and in measurement of specific surface areas of solids. Chem. Soc. 1960, 3973-3993. [CrossRef]

72. Al-Zboon, K.; Al-Harahsheh, M.S.; Hani, F.B. Fly ash-based geopolymer for Pb removal from aqueous solution. J. Hazard. Mater. 2011, 188, 414-421. [CrossRef]

(C) 2020 by the authors. Licensee MDPI, Basel, Switzerland. This article is an open access article distributed under the terms and conditions of the Creative Commons Attribution (CC BY) license (http://creativecommons.org/licenses/by/4.0/). 